\title{
CONFLICT AVOIDANCE IN THE LAW OF PATENTS AND TRADE-MARKS
}

\author{
Peter Meinhardt*
}

INTRODUCTION

The law of patents and trade-marks is notoriously difficult and complex, but from the aspect of the conflict of laws, it is relatively simple. Situations and relations in which a conflict of laws arises are not frequent, and when they do occur, the applicable law is, in the majority of cases, easy to determine. Therefore, the conflict of laws is much more of a fringe problem to the patent and trade-mark lawyer than to the commercial lawyer. ${ }^{1}$

Two cardinal problems continually face the patent and trade-mark lawyer: Is the patent or trade-mark valid? Is it infringed? There is only one law applicable to these problems-namely, the law of the country where the patent or trade-mark was granted and/or is registered, the so-called "country of protection"--and, accordingly, no conflict of laws can arise in these connections. ${ }^{2}$ Furthermore, proceedings for the revocation of a patent or for declaring a patent null and void, as well as proceedings to expunge a trade-mark from the register, can be heard only in the country of protection. ${ }^{3}$ Thus, for example, if an Englishman, $E$, owns a German patent and another Englishman, $F$, wishes to institute proceedings to have the German patent declared null and void, $F$ must institute the proceedings in the German Patent Office and cannot bring the case before the British Patent Office or the English courts, even if $E$ agrees. This follows from the fact that a monopoly granted by the government of one country cannot be revoked by the courts or offices

* Dr. Jur., University of Freiburg, Germany. Of the Inner Temple, Barrister-at-Law; Legal Adviser to British and German companies on patent and trade-mark law. Author, Inventions PaTENTS AND Monopoly (2d ed. 1950). Contributor to legal periodicals.

${ }^{1}$ Although the international conventions and agreements relating to patents and trade-marks are of great importance to the owners of industrial properties and their lawyers, they are but agreements between states and bind-directly or indirectly through domestic legislation-only the patent offices of member states; they do not deal with private international law or the conflict of laws. See generally Kronstein and Till, $A$ Reevaltation of the International Patent Convention, 12 LAw \& Contemp. ProB. 765 (I947); D. M. Kerly, Law of Trade-Marks and Trade Names 697, 903 (7th ed., Lloyd \& Bray I95I); and 3 Rudolf Callaman, Unfair Competition and Trade-Marks app. xix-xxii (I945).

"It is significant that no leading treatise on American, British, Canadian, French, German, or Swiss patent and trade-mark law devotes a chapter to the conflict of laws, or even mentions the subject in its index. Conversely, with possibly one exception, see Clive M. Schmitrmoff, The English Conflicr of LAws 13, 14, 205, 212,418 (3d ed. 1954), the leading treatises on the conflict of laws deal only briefly, if at all, with patents and trade-marks. E.g., Rabel confines his treatment of the subject to a few lines quoting a small number of cases to the effect that a patent or trade-mark can be infringed only in the country of protection. See 2 ERnst Rabel, The Conflict of Laws 295 (I950).

${ }^{3}$ It has been argued, however, albeit unconvincingly, that courts at the domicile of the defendant should also be competent to hear aullity proceedings. See Alous Troller, Das Internationale PrivatuNd ZivilprozessRecht in Gewerblichen RechtsSCHUTZ und URHEBERRECT 239 (I952). 
of another. Similarly, proceedings for the infringement of a patent or trade-mark can be instituted only in the country where the infringement has occurred-that is, the country of protection-again reflecting the territorial effect of the grant. ${ }^{4}$

Transactions in which a conflict of laws may arise, however, comprise the following: assignments of patents, licenses under patents, service agreements with inventors, contracts for the sale or hire of patented articles, patent clauses in cartel agreements, assignments of trade-marks, agreements to use trade-marks, and contracts for the sale or hire of branded goods. The jurisdiction of courts over these matters is determined by the same general rules that determine the competence of courts to hear actions concerning other contracts. Accordingly, the court can always entertain a case if the defendant either is within or has submitted to its jurisdiction. In addition, the court can hear a case if the contract was made within, has been broken within, or is otherwise governed by the law of its jurisdiction. Jurisdiction may also exist in other special situations. Consequently, courts of one country may have jurisdiction to entertain disputes relating to contracts dealing with patents or trade-marks registered in another country. ${ }^{5}$

In this article, we shall first examine how the private international laws of particular countries-i.e., their national laws-resolve such conflicts of law as may arise if the parties themselves fail to do so; then, the cases in which conflict-avoidance clauses are desirable and the extent to which national laws will give them effect.

\section{II}

\section{Conflicts in Contracts Relating to Patents}

The essential validity - as opposed to the formal validity ${ }^{6}$ of a contract relating to patents is governed by the law of the country of protection, unless the parties have expressed a different intent. ${ }^{7}$ Application of this principle was recently illustrated in British Nylon Spinners Ltd.v. Imperial Chemical Industries Ltd. ${ }^{8}$ There, certain British and Commonwealth patents, originally the property of the American Du Pont Company, were assigned to ICI, which, in turn, agreed to grant BNS an ex-

4See 2 Rabel, op. cit. stipra note 2, at 295 for American law; Martin Wolfp, Private InternaTHONAl LAW 494 par. 47 I (1945) for English law; and Trozler, op. cit. stupra note 3, at 266 for Continental law generally. In special cases, however, the proceedings may possibly be brought at the domicile of the defendant-at any rate, with his consent. Id. at 270 .

'See Schmithoff, op. cit. supra note 2, at 433 .

'The general rules of the conflict of laws relating to the form of contracts apply in the field of patents and trade-marks. Accordingly, the evidential form of the contract must comply with the lex fori, sec Schurtiroff, op. cit. supra note 2, at 402; and the substantial form of the contract must comply with the "proper law" of the contract-usually the lex loci contractus or the law of the country of pro. tection. Id. at IIg. Some countries, such as France, however, consider the question of form to be d'ordre public and insist that for French patents and trade-marks, French law be observed. See Trouten, op. cit. supra note 3 , at 177 .

The form of the documents required to enter the assignment of or the license under a patent or trademark in the register must always comply with the law of the country of protection. A. V. DICEY AND J. H. C. Morris, The Conflict of Laws 5 I2 (6th cd. 1949).

${ }^{7}$ This follows from the general rule that the proper law of contracts relating to choses in action is the lex situs or the lex causae. See Schmirrhoff, op. cit. supra note 2, at 211.

${ }^{3}$ [1953] I Ch. I9 (C.A.). 
clusive license thereunder. Before the formal license was executed, however, judgment was given by a United States District Court, ordering ICI to reassign the patents to $\mathrm{Du}$ Pont, subjecting the patents to compulsory licensing, and decreeing immunity to persons importing into Britain articles covered by the patents lawfully manufactured in the United States. ${ }^{9}$ The United States court, however, was most careful to explain that its judgment was directed against ICI in personam and that its effectiveness, therefore, depended on the recognition it would be accorded as a matter of comity by the courts of the foreign sovereign who had granted the patents in question. BNS then brought an action against ICI for specific performance of their agreement, which ICI resisted, pleading in bar the judgment of the United States court. In dismissing an appeal from an interim injunction restraining ICI from reassigning the patents to Du Pont, the Court of Appeal, through Sir Raymond Evershed, M.R., observed:10

An English patent is a species of English property of the nature of a chose in action and peculiar in character. By English law it confers certain monopoly rights, exercisable in England, on its proprietor. A person who has an enforceable right to a licence under an English patent appears therefore to have at least some kind of proprietary interest which it is the duty of our courts to protect. And, certainly so far as the English patents are concerned, it seems to me with all deference to his Honour's judgment, to be an assertion of an extra-territorial jurisdiction which we do not recognize, for the American courts to make orders which would destroy or qualify those statutory rights belonging to an English national who is not subject to the jurisdiction of the American courts.

Subsequently, relying on this exposition, the court granted specific performance of the agreement and ordered ICI to execute the exclusive licenses to BNS so that they could be entered in the register of patents.

Both parties in this case were British firms, but the reasoning of the Court of Appeal that rights under a British patent, being a species of English property, must be protected by the English courts goes far to sustain the rule that the essential validity and effect of contracts to assign patents and to give licenses thereunder are governed by the law of the country of protection, irrespective of the nationality or domicile of the parties. Nor is this rule in conflict with the earlier case of Actiengesellschaft für Cartonnagen Industrie v. Temler $\mathcal{E}$ Seeman. ${ }^{11}$ There, the by-laws of a German company stipulated that a certain German inventor, who, as co-founder, had signed them, should, for a limited period, transfer to the company all his further inventions and the resulting patents in a particular field. The English court, in construing the by-laws and the resulting obligation to assign certain British patents, looked to German law. This case is, however, distinguishable, in as much as the obligation to assign the British patents arose not from an ordinary contract, but rather from the by-laws of the German company-which, of course, have to be

${ }^{\circ}$ United States v. Imperial Chemical Industries, 105 F. Supp. 215 (S. D. N. Y. 1952).

${ }^{10}$ [I953] I Ch. at 26.

1218 R. P. C. 6 (190r). 
construed according to German law. ${ }^{12}$ In the context of Continental law, it may be observed, this rationale has been ratified and justified by the following reasoning: The monopoly situation is in the country of protection, and agreements relating to the disposal of rights under inventions and patents have their economic center and point of gravity in that country. Accordingly, if the contract deals only with patents granted in one particular country, the law of that country will govern the contract. ${ }^{13}$

The matter becomes more complicated, however, if the contract deals with the assignment of or licenses under patents granted or to be granted in two or more countries. Let us take, for example, the case where an inventor sells to a corporation his rights in his inventions in a particular field together with the resulting patents in all countries of the world, and a dispute arises as to the extent of his obligation. There appears to be general agreement that the entire transaction-i.e., the essential validity of the contract, embracing such issues as the capacity of the parties, necessity of consideration, invalidity of the contract because of restraint of trade, etc., as well as its interpretation and the quality and effect of the rights and duties arising thereunder -should be governed by the same law. ${ }^{14}$ Thus, an eminent writer has observed: $:^{15}$

The contract is a unity even though it results in the transfer of individual rights in individual countries. The purchaser intends to exploit the invention in accordance with a uniform plan; the territorial frontiers and the individual territorial laws may impede the central economic concept but cannot cancel it. If several, say twenty or thirty countries, are involved the contract as a unity has a relation of equal intensity to each of them. The contract has to be performed in the total economic space and not in each territory individually.

Nevertheless, there remains the problem of ascertaining which law should be applied. If both parties are nationals of or domiciled in the same country, their personal law will usually be decisive because this can be presumed to have been their intent; if not, and if their personal laws differ, the general rules of the conflict of laws must be invoked. The Continental conflicts rule appears to favor the law of the domicile of the assignor because it is he who essentially implements the contract. ${ }^{16}$ The Anglo-American conflicts rule, however, is less readily discernible, since there appears to be no case authority directly in point, although certain factors would, it is submitted, significantly influence any decision in the matter. Thus, if the assignor is the inventor, and if he has assigned not only his inventions and patents at the date of the contract, but also future inventions in the same field and his improvement patents, there is a presumption that his personal law should govern the contract. Similarly, if the invention originated in the assignor's research laboratory or pilot factory which must continue to supply technical know-how to the assignee,

${ }^{12}$ But see 3 RaBEL, op. cit. stpro note 2, at 73.

${ }^{13}$ See Troller, op. cit. supra note 3 , at 187,188 .

${ }^{14}$ See SchmitthofF, op. cit. supra note 2, at 123 .

${ }^{15}$ TroLler, op. cit. supra note 3 , at 189 .

${ }^{16}$ See Troller, op. cit. supra note 3 , at 191 . 
there again is a presumption that the personal law of the assignor should prevail. On the other hand, if further research or the construction of the pilot factor must be undertaken by the assignee, this may suffice to apply the personal law of the assignee. Somewhat analogously, the personal law of the licensee may govern the contract if his license is exclusive, particularly if the licensee must pay the renewal fees and is required to take all steps to keep the patent in force, such as, for example, active commercial exploitation to avoid compulsory licenses or revocation. Another ground supporting application of the personal law of the assignee or licensee may be existence of an obligation on him to sue infringers at his own expense.

However, even if the court, in resolving the conflict of laws, holds that a foreign law, such as the personal law of one of the parties, governs the contract, this determination will apply only to the relations between the parties; with respect to the rights of third parties, the law of the country of protection will again be held to prevail. Let us take, for purposes of illustration, the case where $F$, a German registered owner of a British patent, assigns the patent first to a German, $G$, who is not entered in the British register, and then to another German, $H$, who has no notice of the first assignment and is entered on the British register. Under German law, $G$, being the first assignee, has the better title; ${ }^{\mathbf{1 7}}$ on the other hand, under English law, $H$, being a bona fide purchaser, has the better title. ${ }^{18}$ If a dispute should arise between $G$ and $H$ regarding the ownership of the British patent, it would be decided by an English court in accordance with English law, despite the fact that the contract between $F$ and $G$, as well as that between $F$ and $H$, are admittedly governed by German law.

Special considerations will also arise if provisions for the assignment of or for a license under a patent form part of a more comprehensive contract. Let us take, for example, the case where an obligation to assign patents forms part of a service agreement between an employer and an employee which specifically provides that all inventions made by the employee in the field of activity of the employer shall belong to the employer-or where this may be implied by law in the absence of an express provision to that effect. If the employer and the employee are domiciled in different countries, the question of which law applies to the service inventions will depend on which law applies to the entire service agreement. The personal law of the parties, the country where the services are to be performed, and possibly the place where the contract was concluded will be decisive factors; the country of protection of the patents will be only of secondary importance. ${ }^{19}$

Agreements relating to the assignment of or licenses under patents may also form part of a partnership agreement or an agreement for the formation of a company or a joint venture; using the German expression, they may form part of a Gesellschaftsvertrag. For example, an English and a Dutch company may

${ }^{17}$ See Reimer, Patentgesetz 399, 718 (1949).

${ }^{18}$ See Thomas Terrell and Courtnex Shelley, The Law of Patents 248 (1952).

${ }^{19}$ See Arnold Seligsohn, Patentgesetz I13 (I932); Troller, op. cit. supra note 3 , at 193. 
join forces to build oil refineries in various South American countries, including, say, Colombia and Venezuela, and form local companies in these two countries for that purpose, granting licenses to them under their respective local patents. If we assume that Dutch law governs the general provisions of the contract between the two parent companies as well as the contracts between the two parent companies and the local subsidiaries, Dutch law will govern also the the rights and obligations of the parties concerning the Venezuelan and Colombian patents and the licenses thereunder, and the law of the country of protection-i.e., Colombia and Venezuelan law -will not apply.

Patent licenses may also form part of contracts for the sale or hire of goods. The simplest case is the sale of an article covered by a patent. If there is nothing to the contrary in the contract, the law, of course, implies in all countries that the purchaser has a license under the patent of the vendor to use and resell the article purchased. ${ }^{20}$ If, however, the vendor attaches express restrictive conditions to the sale, then the implied license to the purchaser may, depending on the applicable law, be limited by these restrictions. Let us take, for example, the case where an English manufacturer sells to a German importer a radio tube covered by a British and a corresponding German patent belonging to the manufacturer. The contract expressly provides that the tube shall be used only in a receiver (not covered by patents) made and supplied by the manufacturer. In breach of this condition, the purchaser uses the tube in a receiver supplied by a third party. Under English law, such a restrictive condition prohibiting the purchaser from using articles not supplied by the vendor is void, ${ }^{21}$ whereas in Germany it is valid. Whether English or German law applies here must be decided in accordance with the general rules of the conflict of laws concerning contracts of sale, irrespective of the patent aspect.

These conflicts rules, of course, do not operate in a vacuum, and their application may be tempered by overriding public policy considerations. Thus, the exchangecontrol regulations of Great Britain and many Continental countries-which govern the sale of a patent to a foreigner, the payment of the purchase price for a patent to a foreigner, the grant of a license under a patent to a foreigner, and the payment of royalties for a license under a patent to a foreigner-will be applied by the courts, irrespective of the law otherwise governing the contract. ${ }^{22}$ Let us take, for example, the following case: A French patentee, $F$, sells his French patent to an Italian, $I$, and the contract provides that Swiss law shall apply. Under French and Italinn exchange-control law, permission would be required; under Swiss law, such permission would not be necessary. If application by the parties to the French and Italian exchange-control authorities for a permit has been unsuccessful, the French as well as the Italian courts will hold the contract void. Thus, although the Swiss

${ }^{20}$ Sce Terrell \& SHeller, op. cit. stipra note 18 , at 259.

${ }^{21}$ Patents Act, I949, 12, I3 \& $\mathrm{r}_{4}$ Gro. 6, c. 87, $\$ 57$.

${ }^{23} \mathrm{Cf}$. Boissevain v. Weil, [1950] A. C. 327 , in which the House of Lords held the British exchange control law and regulations to be applicable by English courts, even where they arrogate to themedies extraterritorial effect, or where another law otherwise governs the transaction. 
courts may regard the contract valid under their law, a Swiss judgment recovered thereon by one of the parties will be unenforceable in France or in Italy. ${ }^{23}$

Cognate cases are those in which patent licenses and agreements to exchange technical know-how form part of international cartel agreements. The arrangements will generally apply to patents in all countries covered by the cartel, and one designated law will apply uniformly to the entire contract, irrespective of the country in which a particular patent was granted. Frequently, the designated law is that of some country having no anticartel or antimonopoly legislation, such as Switzerland. Prima facie, that law will, then, apply to the patent clauses in the cartel agreement, such as those providing for mutual patent licenses and undertakings not to oppose patent applications of other members. But, since anticartel and antimonopoly laws reflect a strong public policy of a state, here, too, they will be applied by the courts of that state, irrespective of the law purportedly governing the contract. Let us take, for example, the following case: A cartel agreement relating to radio and television tubes, governed by Swiss law, provides that a member shall be licensed under the patents of other members only in countries where the licensee has a sales quota under the cartel and that a member shall not apply for a compulsory license in a country where he has no quota. Assume that an English member of the cartel has no quota in England for a certain type of television tube because in the basic year when quotas were established all such tubes were imported into England from Germany. The English cartel member then commences to manufacture such tubes in England, thereby infringing a British patent owned by the German cartel-member. After unsuccessfully seeking a license, the English member applies to the British Patent Office for a compulsory license under the British patent of the German member. The Comptroller of the British Patent Office will grant the compulsory license-provided all other conditions are satisfied ${ }^{2 \cdot 3}$ - since the undertaking of the English member not to apply for the compulsory license will be held unenforceable as being contrary to English public policy, even if valid under the Swiss law applicable to the cartel agreement. It should be noted, however, that the compulsory license thus granted will apply only to the British patent; and if the German cartel-member holds corresponding patents abroad, he will still be able to stop the sale abroad of articles made by the compulsory licensee in England on the strength of the patents he holds in the foreign country of sale. ${ }^{25}$

These cases and examples demonstrate that where all patents comprised in a contract are granted in a single country, the contract will normally be governed by the law of that country, being the law of the country of protection. Consequently, in such a case, a conflict-avoidance clause will not normally be necessary, although it may still be advisable to insert one as a matter of precaution. Where, however, both parties to a contract are nationals of or domiciled in the same country, being a coun-

${ }^{23}$ On exchange-control in Great Britain, see Ch.ive M. Schmitthofr, The Export Trade c. 26 (3d ed. 1955).

${ }^{26}$ See Patents Act, 1949, 12, I3 \& I4 Geo. 6, c. 87, \$37.

${ }^{25}$ See Blanco White, Patents for Inventions 272 (1955). 
try different than the country of protection, there may be some question as to whether the personal law of the parties or the law of the country of protection was intended to govern the contract, and in this special case, therefore, it is desirable to insert a conflict-avoidance clause into the contract. Usually, the parties will prefer their own personal law, both because they are familiar with it and because litigation in their own home country is likely to be more convenient and less expensive for them. Even if the parties choose their personal law, however, questions concerning the validity of any foreign patent will, nevertheless, have to be decided in accordance with the law of the country of protection.

On the other hand, where a contract deals with rights to patents granted in different countries, difficult problems of the conflict of laws are likely to arise. In such a contract, therefore, a conflict-avoidance clause is essential. It should be noted, however, that even if the parties choose a law other than that of the country of protection, this will not enable them to escape regulations forming part of the public policy of the country where they exercise rights under individual patents covered by the contract. This is true particularly as regards exchange-control regulations and provisions to prevent the abuse of monopoly.

\section{III}

\section{Conflicts in Contracts Relating to Trade-Marks}

In the field of trade-marks, as in the patent field, the principle of territoriality applies, and the law of the country of protection governs the contract, unless the parties have expressed a different intent. ${ }^{26}$ Thus, if all the trade-marks assigned by a contract are registered in a single country, the law of that country-the country of protection-will usually govern the contract.

The problem becomes more difficult, however, if the marks are registered in several different countries. Let us take, for example, the case where a firm has businesses, goodwill, and trade-marks in many different countries and transfers the businesses, goodwill, and trade-marks in all these countries to another firm by a single contract. If the contract does not indicate which law shall apply-a situation for which there appears to be no case authority directly in point-it has been suggested that the transfer be considered a uniform transaction and that the law at the domicile of the transferor prevail. ${ }^{27}$ It would seem, however, that this proposal is too sweeping, and it is submitted that each case rather must be examined and decided on its merits. If the existence of the contract as a whole is at issue, for example, because the capacity of the parties to contract is in dispute, then the law at the seat of the assignor may perhaps properly apply. If, however, the effect of the global contract on the assignment of trade-mark is at issue only in an individual country, then it may be preferable to split the contract into its various territorial components and to apply the law of the appropriate country of protection to the dispute.

${ }^{20}$ See note 7 supra.

${ }^{27}$ See Troller, op. cit. supra note 3 , at 202, 217. 
Special consideration is also indicated where a trade-mark is purely an export mark or is associated with a branch or subsidiary abroad-in which latter case, the law of the country of protection will certainly govern. Even if the personal law of the assignor of the various marks in the different countries governs the contract as a whole, however, the regulations of the country of protection as regards the formalities of transfer, ${ }^{28}$ the assignment with or without goodwill, ${ }^{29}$ and the regulations regarding permitted or registered user ${ }^{30}$ must always be strictly observed.

Problems of conflict of laws may also arise where the articles branded with registered trade-marks are shipped from one country to another under contracts imposing price-maintenance and similar obligations. In seeking to ascertain the law governing these transactions, distinction must be drawn between (a) the relation between the vendor and the purchaser; (b) the relation between the vendor and third party resellers; and (c) the relation between the vendor and another vendor. Let us take the following examples:

Case a: A vendor in Holland sells branded goods to an importer in Germany, where the brand is registered for the Dutch vendor as a trade-mark, and stipulates that they shall not be resold under a certain price. The German importer resells under the stipulated price, and the Dutch vendor sues him in Germany. The question whether German or Dutch law applies is governed by the ordinary rules of the conflict of laws on contracts of sale, and the fact that the trade-mark is registered in Germany is of minor importance.

Case b: Varying the example, let us assume that the importer resells at the stipulated price, but that a third-party retailer, with knowledge of the price clause, resells below the list price. Since there is no privity of contract between the thirdparty retailer and the Dutch vendor, the vendor cannot sue for breach of contract, nor can he sue for trade-mark infringement, as the mark is genuinely used on the goods. If, however, the vendor has, throughout, rigidly maintained list prices for his branded goods in Germany, he can, in certain cases, sue the retailer in Germany for unfair competition; ${ }^{31}$ and since this action sounds in tort, the question of what law shall apply to the original and subsequent contracts of sale is irrelevant.

Case c: Various manufacturers of branded goods in a particular line agree not to sell their branded goods of a certain quality or size below a certain price-in other words, they form a trade association or a cartel. If the manufacturers are from different countries, problems of conflict of laws are bound to arise, and in such cases, the agreement will invariably contain a conflict-avoidance clause. Usually, as is the case in a patent contract, the law of a country with no or a few anticartel regulations, such as Swiss law, is chosen. However, laws declaring price-maintenance agreements unenforceable or illegal are often regarded as manifestations of a strong

${ }^{28}$ See note 6 supra.

${ }^{30}$ See notes 33 and 34 infra.

${ }^{30}$ See note 37 infra.

${ }^{31}$ Gesetz gegen den unlauteren Wettbewerb I909, \$I. See also BaUMBach KoMMmentar zUM WETTBEWERBSRECHT 523 (1929), and REIMER WETTBEWERPSRECHT 566 (1954). 
public policy, and, consequently, courts frequently will apply the lex fori on trusts, restrictive practices, and cartels. Even where unenforceable in the courts, however, such agreements, in practice, are often enforced by extrajudicial means. ${ }^{32}$

The laws of many countries provide that a trade-mark can be assigned only together with the goodwill or business to which it belongs; ${ }^{33}$ and where it exists, this requirement must be observed, irrespective of the law governing the contract of assignment. ${ }^{34}$ Let us take, for example, the following case: A Frenchman, $F$, has a perfume factory in Germany and there sells perfume made in that factory under a trade-mark registered in Germany. By a contract concluded in France, expressly providing that French law shall apply, $F$ assigns the German trade-mark to another French perfume manufacturer, $G$, but keeps and continues to operate his factory in Germany, now selling his perfume in Germany under a different mark. $G$, on the other hand, starts selling in Germany perfume made by him in France and brands it with the trade-mark assigned to him by $F$. On the strength of an inaccurate declaration regarding simultaneous assignment of the product made to the German Patent Office, the purchaser, $G$, is enrolled on the German register of trade-marks as owner of the mark. Subsequently, a third manufacturer, $H$, starts a perfume factory in Germany and brands his perfume with the same mark. $G$ institutes suit against $H$ for infringement, relying on his registered trade-mark, to which $H$ interposes the defense that the plaintiff has no title to the mark, since its transfer to him without the business is void under German law. ${ }^{35}$ The plaintiff replies that the contract of assignment was governed by French law, which does not requires simultaneous transfer of the business. Holding that the requirement of the simultaneous transfer of the business forms part of public policy, the German court will apply German law and dismiss the case, despite the fact that the contract of assignment between $F$ and $G$ may otherwise be governed by French law. It is a moot point in German law whether the original owner of the mark can be restored to the register and then sue the infringer, or whether the mark has been completely destroyed. ${ }^{36}$ In any event, it is seen that the conflict-avoidance clause may prove a trap to the unwary.

${ }^{32}$ See Committee on Resale Price Maintenance, Report, CMp. No. 7696, at par. 144 (1949); and Commission on Collective Discrimination, Report of the Monopolies and Restrictive Practices, Cm. No. 9504 (r955). See also British Restrictive Trade Practices Bill, Bill 99 of 1956, \$19, outlawing collective enforcement of resale prices, and $\$ 20$, sanctioning individual enforcement.

${ }^{33}$ This rule obtains today in, e.g., the United States, U. S. Trade Mark Law of 1946, 60 Stat. 43r, I5 U. S. C. $\$$ ro6o (I952); and Germany. Warenzcrchengesetz I953, \$8. It also obtained in Grcat Britain prior to 1938 , British Trade Marks Act of 1905, 5 Enw. 7, c. 15, \$22; but today a British trademark can be assigned without the goodwill or business to which it belongs, provided the assignce advertises the assignment in accordance with prescribed directions. British Trade Marks Act, 1948, I \& 2 GEo. 6, c. 22, \$22. In France, on the other hand, trade-marks are assignable free of any such restrictions. Sce P. O. Hereward, Handbook on Trade Mark Laws Throvghout the World 72 (1951).

${ }^{34}$ The severity of this rule, however, is mitigated by art. 6 quater of the International Consention for the Protection of Industrial Property of March 30, 1880 , as revised in London, June 2, 1934, which provides that it shall be sufficient if that portion of the goodwill or business is transferred which is situated in the country of assignment.

${ }^{35}$ See note 33 supra.

${ }^{30}$ See Rudolf Busse, WarenzeicheNgesetz 209 n. $46 \$ 8$ (1939). 
Similarly restricted in the use of his property is the owner of a trade-mark who wants to give to another permission to use his mark-in other words, to grant a license under the mark. The laws of many countries prohibit licenses in respect of trade-marks, and the grant of such a license in these countries, coupled with the use of the mark by the grantee in defiance of the law, will render the mark void. ${ }^{37}$ Let us take the following example: A Frenchman, $F$, is the registered owner of a British trade-mark for ladies' dresses. In the past, $F$ has imported dresses bearing this mark into England from France. He now forms a subsidiary company, $E$, in England and grants to $E$ a license to use the mark, with the express proviso that French law shall apply to the license agreement. No application is made to enter $E$ as registered user in the British register, as is required by British law, but not by French law, ${ }^{38}$ but $E$ starts using the mark. Subsequently, another English firm, $H$, infringes the mark. On being sued by $F, H$ pleads that the mark has become invaiid owing to the use by $E$, who was never the owner nor the registered user. $F$ 's action for infringement of the trade-mark will, it is submitted, be dismissed, although $F$ and $E$ might possibly succeed against $H$ in an action for "passing off." The clause in the contract that French law shall apply to the license to use the mark will, thus, not help the parties if they fail to comply with British law-i.e., the law of the country of protection.

These cases and examples demonstrate that where all trade-marks comprised in a contract are granted in a single country, the contract will normally be governed by that country's law, being the law of the country of protection. Consequently, in such a case, a conflict-avoidance clause will not be necessary. Only if both parties are nationals of or domiciled in the same country, being a country different from the country of protection, will a conflict-avoidance clause be desirable to avoid dispute as to whether the law of the country of protection or the personal law of the parties applies.

On the other hand, where trade-marks in various countries are involved, a conflictavoidance clause is absolutely necessary because the rules of the conflict of laws in such a case are very ill-defined. Irrespective of the law chosen by the parties to apply to the contract, however, it is essential to comply with the ius cogens of the country of protection concerning the assignment of trade-marks, with or without goodwill, as well as the regulations concerning use of trade-marks by third persons, registered users, and related companies.

\footnotetext{
${ }^{37}$ E.g., the owner of a trade-mark registered in the United States must not allow another to use his mark, except where the permittee is a "related company" which controls or is controlled by the registrant in respect to the nature and quality of the goods in connection with which the mark is used. U. S. Trade Mark Law of 1946,60 SrAT. 429, 443, 15 U. S. C. $\$ 1055,1127$ (1952). In Britain, use of the mark by one other than its owner is allowed only if the former is entered in the register as "registered user"; and such an entry will not be accepted unless the registrar is satisfied that the use of the mark rcmains under the control of the registered owner. British Trade Marks Act, 1938, I \& 2 Geo. 6, c. 22, \$28. In other countries following the French system, such as Spain, licenses under trade-marks are permissible. See Hereward, op. cit. supra note 33 , at 72,180 .

${ }^{3 n}$ See note 37 supra.
} 
IV

\section{Arbitration in International Agreements Relating to \\ Patents and Trade-Marks}

Matters touching rights and obligations of the parties to a contract in the field of patents and trade-marks, unlike those affecting the rights of the state, can be referred to arbitration for resolution. ${ }^{39}$ Accordingly, arbitration is possible on questions arising out of agreements to assign patents or trade-marks or out of license agreements under patents, such as, for example, the payment of the purchase price, or calculating the amount of the royalty to be paid under a license agreement, or the amount of damages for breach of contract. On the other hand, the existence of the patent or trade-mark, as such, cannot be affected by the verdict of an arbitration tribunal. Thus, an arbitrator cannot revoke a patent, declare it null and void, or order a trade-mark to be expunged from the register; although where the question of the validity of a patent or trade-mark must be passed upon by an arbitrator only as an incident to his verdict, then he will be empowered to investigate it and to pronounce his view on it. For example, if, in a license agreement, there is an $\mathrm{ex}$ press warranty that the patent is valid, then the arbitrator can and must examine the validity of the patent and dismiss a claim for royalties if he finds the patent invalid.

Similarly, if a patentee, $A$, claims that $B$ infringes his patent and the parties decide by an agreement ad hoc to refer to the dispute to arbitration, $B$ can plead invalidity by way of defense, but he cannot counterclaim for revocation of $A^{\prime} s$ patent, which course would have been open to him if the case had been heard by the court.

These principles apply not only to disputes between two parties who are nationals of or domiciled in the same country, but also to disputes with an international aspect. Apart from issues concerning the validity of the patent or trade-mark, where the law of the country of protection must be applied, the arbitrator will, in either case, have to apply the law governing the contract. This latter is, prima facie, presumed to be the law at the seat of the arbitration tribunal. ${ }^{40}$ Let us take, for example, the following case: A license agreement between a German licensor and an English licensee contains the following clause:

All disputes under this agreement shall be decided by arbitration in London, in accordance with the Arbitration Act, I950.

If, then, a dispute arises regarding payment of royalties by the English licensee under patents granted in several countries-say, Germany and England and Switzerland and France, so that the law of the country of protection gives no indication of the intention of the parties-English law will govern the contract because the arbitration takes place in London. If, however, the same clause is contained in a contract

\footnotetext{
${ }^{38}$ See Davis, Patent Arbitration, A Modest Proposal, ro ARr. J. 31 (1955); Deller, Extent and Usefulness of Arbitration in Settling Patent Disputes, 3 ARs. J. 100 (1948).

${ }^{10}$ See Schmiтrнoff, op. cit. supra note 2 , at 486 .
} 
dealing only with German patents, the presumption that German law, as the law of the country of protection, shall apply will probably oust the presumption that English law, as the law of the country of arbitration, shall apply. Counsel for the German licensor could successfully argue that arbitration in London was chosen only because it would be easier to enforce an award against the licensee, ordering him, for example, to pay royalties, if it was rendered by an English arbitrator sitting in London than by a German arbitrator sitting in Germany, and that the parties, nevertheless, wanted the dispute relating to the German patents to be decided by German law.

International cartel agreements, which frequently contain provisions that all members shall, on payment of a royalty, be licensed under the patents of another member, usually contain arbitration clauses. Typical is the International Lamp Cartel Agreement of I924, which bore the title "General Patent and Business Development" and was known as the "Phoebus Agreement."41 The arbitration clause was contained in article 19 , which provided:

In the event of disputes between parties to this Agreement such disputes shall be submitted to the General Meeting or the General Board for decision. . . . All disputes arising from the decisions and acts of the General Board may be appealed from only to and shall be settled by a Tribunal of Arbitration to be elected by the General Board subject to the approval of the General Meeting. The Tribunal of Arbitration shall be composed of three or more impartial persons who shall base their decisions on justice and equity in accordance with the obvious intent and purpose of the parties and the said decision shall be made by majority vote. Its decision shall be final and binding.

And article 22 further provided that the parties

4 Patent matters were treated in art 4, which provided:

A. Existing contracts between any parties hereto relating to patents and experience covering lamps or the methods or appliances of their manufacture are hereby extended by such parties to the expiration of their agreement.

B. Where it is possible for a party to obtain specific advantages given him by this Agreement only by using an invention owned or controlled by another party or by the use of another party's experience not at the time available by any other agreement, such first party shall be licensed under the patents necessary therefor and/or shall have such experience available for the period both parties shall be bound by this Agreement under the terms and conditions ordinarily applied by the second party to such a situation. Licence contracts already in force as well as the royalties usually paid in the lamp trade and the services to be rendered shall be taken into consideration in fixing the terms and conditions. Lack of agreement regarding conditions shall not operate to prevent use of inventions or experience. Suitable security for the payment of royalty or service charges for such use must be deposited with the management [of the cartel organization]....

C. (I) Disputes or disagreements arising under the foregoing section will be settled by the Tribunal of Arbitration which Tribunal, however, shall in such cases co-opt one or more impartial persons experienced in patent matters.

(2) Except by the beforementioned procedure of arbitration, which shall apply only between the parties in dispute and within the scope, territory, and term of this Agreement, no opposition against a patent or patent application will be possible during the continuance of the Agreement.

D. No license and/or experience granted under or in pursuance of this article shall itself operate to relieve any grantee from any obligation included in any other agreement which it may have with the grantor.

E. Nothing in this Agreement may be interpreted as a licence to or as an agreement to licence any party to manufacture in any country where it is not now manufacturing. 
... shall recognize as the forum prorogatum in every case where the forum or tribunal is not specifically provided for under the terms of this Agreement, the Common Courts of the Canton of Geneva, Switzerland. This provision shall apply especially to those parties who refuse to be bound by the arbitration clauses of this Agreement on the ground that they are nationals of a country the legislation of which does not recognize general arbitration.

The provisions of the Phoebus Agreement relating to patent licenses were, in fact, so well drawn, that few disputes arose; but those that did arise were settled expeditiously and to the satisfaction of the parties under the arbitration procedures prescribed.

\section{$\mathrm{V}$}

\section{Form of Conflict-Avoidance and Arbitration Clauses}

The patent and trade-mark lawyer must consider when he should advise his client to insert a conflict-avoidance or arbitration clause into a contract and when such a clause would be inoperative or undesirable. Once he has decided that he does want such a clause, he should turn to the formulae evolved by the specialists in the general field of the conflict of laws and follow the precedents worked out by them. ${ }^{42}$ Accordingly, a simple conflict-avoidance clause in a contract with international aspects relating to patents and trade-marks might read:

This contract, including its construction, validity, and performance, shall be governed by [e.g., Swiss] law.

In addition to the choice-of-law clause, as has been indicated, a clause stipulating the courts competent to decide disputes may also be advisable in international agreements relating to patent and trade-marks. Here, a clause might, for example, read:

All disputes under or relating to this agreement shall be decided by the courts of [e.g., Switzerland];

or,

The courts of [e.g., Switzerland] shall be exclusively competent to decide any disputes under or relating to this agreement.

Such choice-of-jurisdiction clauses, it should be noted, however, although permissible under the laws of most European countries, are frowned upon by American courts if they tend to oust their jurisdiction. ${ }^{43}$

A clause regarding address for notices may also be useful in international agreements relating to patents and trade-marks. It might read:

Any notice under this agreement can be served on the parties hereto by registered letter sent to their address given herein.

${ }^{43}$ See Scrimitrhofr, op. cit. supra note 23 , at 46 .

${ }^{43}$ See Eugen Langen (Ed.), Internatronale Lizenzvertráge 27 (1954). 
Where arbitration is indicated, provision may be made for adherence to the rules of the International Chamber of Commerce, which recommends the following arbitration clause $:^{44}$

All disputes arising in connection with the present contract shall be finally settled under the Rules of Conciliation and Arbitration of the International Chamber of Commerce by one or more arbitrators appointed in accordance with the Rules;

or the American Arbitration Association, which recommends the following clause in contracts involving foreign trade: ${ }^{45}$

Any controversy or claim arising out of or relating to this contract, or the breach thereof shall be settled by arbitration in [e.g., New York] in accordance with the Rules of the American Arbitration Association and judgment upon the award rendered by the arbitrator(s) may be entered in any court having jurisdiction thereof;

or the following clause may be used:

(I). All disputes arising in connection with the present contract shall be finally settled by arbitration.

(2). Arbitrations held outside the United States of America shall be conducted in accordance with the Rules of the International Chamber of Commerce (unless by written agreement of the parties they adopt the Rules of the American Arbitration Association).

(3). Arbitrations held in the United States of America shall be conducted in accordance with the Rules of the American Arbitration Association (unless by written agreement of the parties they adopt the Rules of the International Chamber of Commerce).

(4). Judgment upon the award rendered may be entered in any court having jurisdiction or application may be made to such court for a judicial acceptance of the award and an order of enforcement, as the case may be.

(If the place of arbitration is determined in advance, either (2) or (3) above should be omitted, and whichever is retained should commence, "Arbitrations shall be held at . . . and shall be conducted. ...")

\section{V}

\section{Conclusron}

In the field of patents and trade-marks, there are few decided cases on problems of the conflict of laws. Nevertheless, the following conclusions may fairly be drawn:

I. If all patents or trade-marks comprised in a contract have been granted in a single country, then the contract will normally be governed by the law of that country, being the law of the country of protection. However, if both parties to the contract are nationals of or domiciled in the same country, being a country different from the country of protection, then the personal law of the parties may, according to the intention of the parties, govern the contract.

2. If the patents or trade-marks comprised in a contract are granted in different

"See American Arbitration Assoctation, The Practice of Commerciar. Arbitration 23i (x928). European experts on patent license agreements have nearly all expressed themselves in favor of arbitration by the International Chamber of Commerce. See LANGEN, op. cit. supra note 43 , at 27 .

25 American Arbitration Association, Commercial Arbitration Tribunals 14 (i94I). 
countries and the parties are nationals of or domiciled in different countries, difficult problems of the conflict of laws are likely to arise, and a conflict-avoidance clause is essential.

3. If the parties choose a law other than that of the country of protection, the rules of public policy of the country of protection, such as exchange-control regulations, provisions against the abuse of monopoly, prohibition of assignment of trademarks without the goodwill, or restrictions in granting licenses under trade-marks, must be observed.

4. In international agreements relating to patents and trade-marks, arbitration clauses are usual and desirable. 